\title{
ENVIRONMENTAL ASSESSMENT FOR \\ DOE PERMISSION FOR OFF-LOADING ACTIVITIES TO SUPPORT THE MOVEMENT OF MILLSTONE UNIT 2 STEAM GENERATOR SUB-ASSEMBLIES ACROSS THE SAVANNAH RIVER SITE
}

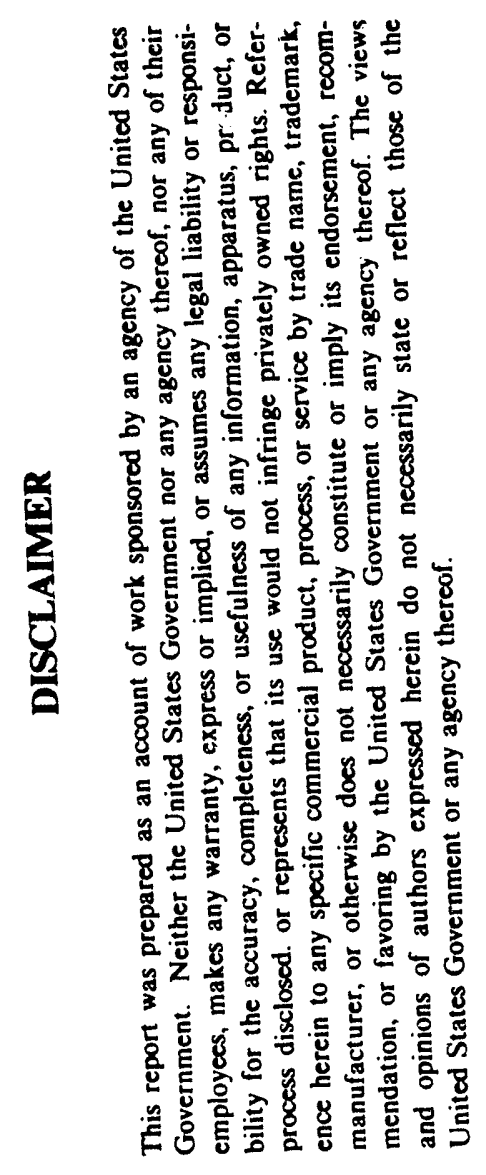

OCTOBER 1992

\author{
U. S. DEPARTMENT OF ENERGY \\ SAVANNAH RIVER FIELD OFFICE \\ AIKEN, SOUTH CAROLINA
}

MASTER 
TABLE OF CONTENTS

1.0 NEED FOR ACTION

2.0 PROPOSED ACTION AND ALTERNATIVES

2.1 Proposed Federal Acticn

2.2 Alternatives to the Proposed Federal Action

2.2.1 Use of Other Docking Facilities

2.2.2 Overland Rail Movement

2.2.3 Overland Road Movement

2

2

2

3.0 ENVIRONMENTAL CONSEQUENCES

4.0 SAFETY IMPACTS 5

4.1 Conventional Safety 5

$\begin{array}{lll}4.2 & \text { Nuclear Safety } & 6\end{array}$

$\begin{array}{lll}5.0 & \text { REFERENCES } & 8\end{array}$

APPENDIXES:

APPENDIX A: Floodplain/Wetland Assessment APPENDIX B: NRC Certification and Safety Evaluation Report APPENDIX C: U. S. Army Corps of Engineers Nationwide Permit 


\subsection{NEED FOR ACTION}

Chem-Nuclear Systems Incorporated (CNSI) maintains and operates the low level radioactive waste burial facility adjacent to the Savannah River Site (SRS) in Barnwell County, South Carolina. As the operating contractor at the Barnwell Facility, CNSI has accepted two oversize/overweight steam generator subassemblies (SGSAs) from the Millstone Unit 2 nuclear power reactor in Waterford, Connecticut for disposal. The two SGSAs, which are low level radioactively contaminated waste, are being replaced, retired from service, and shipped to the CNSI facility by CNSI.

This Environmental Assessment (EA) assesses the potential environmental and safety effects of the U.S. Department of Energy permitting CNSI to use Federal property (SRS), as they have requested, for offloading activities for the two decommissioned SGSAs on their way to the CNSI facility. The SGSA transport barge would make landing at the existing SRS boat ramp, the ramp would be modified as needed for its off-loading, and then the SGSAs would be off-loaded and shipped to the CNSI facility.

Federal permission to use the SRS boat ramp is necessary to enable CNSI to ship the two SGSAs via waterborne traffic, the safest and most economical means of movement for these huge packages. Once offloaded, the SGSAs would be shipped overland using CNSI equipment to their final destination in Barnwell County. The proposed action has no connection to SRS operations and is in no way necessary to support SRS activities.

\subsection{PROPOSED ACTION AND ALTERNATIVES}

As approved by the Nuclear Regulatory Commission (NRC), the decommissioned SGSAs would be prepared for shipment in Connecticut by welding on a cover (top hat) to replace the water/steam separator domes, welding caps on all nozzles, and seal-welding all mechanical closures to form a sealed containment vessel. The internal voids would be filled with low density concrete on both the primary and the secondary sides. The concrete would encapsulate any residual liquid in the sub-assembly tubes. The concrete mixture to be used has a density of approximately $21 \mathrm{lbs} /$ cubic foot. The total volume of the primary and secondary sides of the SGSA is approximately 4,150 cubic feet, thus the concrete would weigh approximately 87,000 lbs.

The application by Northeast Nuclear Energy Company to the NRC was approved June 3, 1992 and constitutes authority to use the package for shipment of radioactive material and for the package to be shipped in accordance with the provisions of 49 CFR 173.471 (NRC, 1992). Each generator package would measure $41^{\prime}-111 / 2^{\prime \prime}$ long and 16'-8 $3 / 7^{\prime \prime}$ wide. They would be loaded onto a specially designed trailer to be moved by large tow tractors. The truck-trailer combination would be 116 feet long, 18 feet wide, 20 feet high, and weigh 1,150,350 pounds. It would be loaded on a sea-going barge in Connecticut for its shipment and driven off of the barge upon its landing at the SRS boat ramp.

\subsection{Proposed Federal Action}

The proposed Federal action is to permit CNSI to use Federal property for its SGSA transport barge to make landing at the existing SRS boat ramp, modify the ramp as needed for its off-loading, and off-load the SGSAs ior their movement to the CNSI facility in Barnwell County. The existing SRS boat ramp was built in the 1950s. The CNSI modification activities at the SRS boat ramp are expected to be minimal in nature and have been reviewed and accepted by the U.S. Army Corps of Engineers (COE) as an action which is authorized under Nationwide Permit \#3 (COE, 1992). More details are provided in Section 3.

According to CNSI plans, the two SGSAs would be packaged and shipped separately, using the same $200 \mathrm{x}$ 40-foot barge and the same 116-foot long truck-trailer combination, both of which are designed to accomrnodate oversize/overweight loads. The first shipment is proposed to begin in mid-October, and the second shipment is proposed to begin the end of November. 
As specified by contract, all expenses associated with the proposed SGSA off-loading activities would be covered by CNSI. This includes all work at the SRS boat ramp, security, sediment sampling and disposal as necessary, mitigation actions required to return the ramp area to its former condition including erosion stabilization, movement of traffic signals and power lines, and any damages which could occur as a result of this nuvement, or the scheduling of this movement across SRS. CNSI would be liable for any accidents which could occur on SRS and all clean-up/repair activities which could result from such an accident.

SRS occupies about 199,000 acres in southwestern South Carolina located 17 miles southeast of Augusta, GA (see Figure 1). The Savannah River boat ramp is located just north of the TNX Area on SRS and is surrounded by wooded areas. The TNX Area is an expanded testing area for the Savannah River Technology Center and contains simulated models and mock ups for SRS development activities. The SRS site contains national defense facilities including five nuclear production reactor areas; two chemical separations areas; waste processing, storage, and disposal facilities; and various supporting facilities.

\subsection{Alternatives to the Proposed Federal Action}

The request by CNSI presents DOE with a decision involving two DOE alternatives; 1) permit the offloading activities(the proposed Federal action), or 2) refuse DOE permission (no action). Alternatives available to CNSI should DOE choose the no action alternative are discussed below.

\subsubsection{Use of Other Docking Facilities}

There is no other dock on the upper Savannah River on the South Carolina side which will accommodate oversize/overweight loads of this magnitude. The Georgia side facilities can not be used because the Savannah River bridges cannot handle the weight. Therefore, other means of barge transport are not a reasonable alternative.

\subsubsection{Overland Rail Movement}

An alternative to the proposed action would be overland rail movement of the SGSAs from Charleston, South Carolina. The barges would be required to make landing at Charleston, SC as no bridges currently spanning the Savannah River are capable of supporting the weight of the SGSA, trailer and tow tractors (combined weight of $1,150,350$ pounds). Once off-loaded in Charleston the SGSAs would be loaded onto a CSX rail car and moved to the SRS railyard, now the closest point to CNSI by rail. Upon arriving at the SRS railyard, the SGSAs would be off-loaded onto trailers and towed the remaining distance to the CNSI Facility. This alternative would require crossing numerous South Carolina railroad bridges in order to traverse the approximate 150 miles from Charleston to Barnwell.

This is not a reasonable alternative because many of the railroad bridges existing between Charleston and SRS have been found to be incapable of sustaining the weight of the SGSAs. In addition, this means of movement would also represent an increased risk of accident. The chance of an accidental derailment is far greater than the possibility of a mishap by waterborne traffic.

\subsubsection{Overland Road Movement}

Another alternative to the proposed Federal action would be the movement of the SGSAs from Charleston, South Carolina to Barnwell, South Carolina via overland highways. This is not considered as an acceptable alternative because of key highway bridges enroute that cannot handle the 1,150,350 pounds of weight and the many underpasses enroute that are lower than 20 feet (most interstate highway underpasses are designed for 14-foot clearance). Numerous low hanging power lines, phone lines, and traffic signals would make 


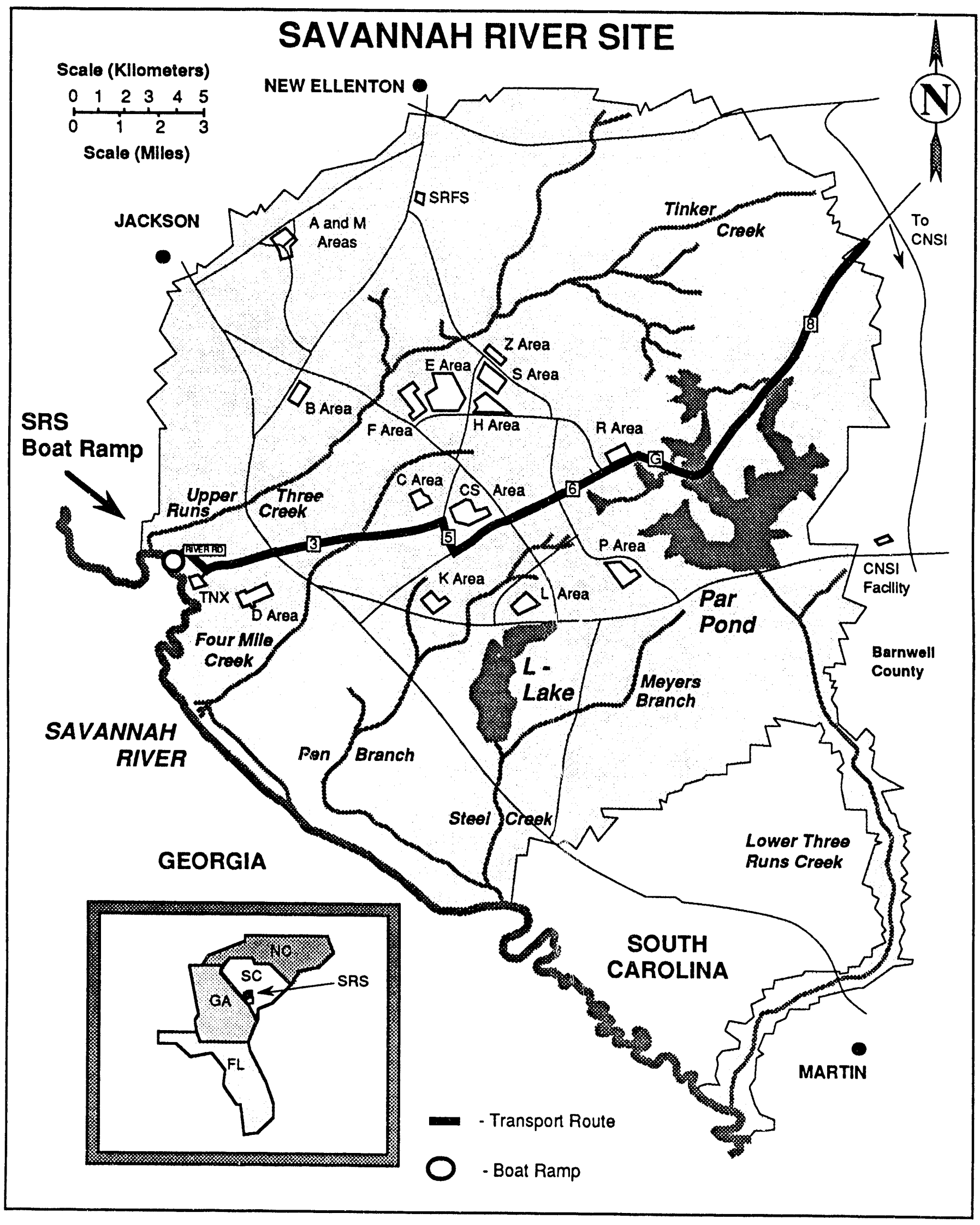

FIGURE 1. Location of SRS Boat Ramp and Transport Route 
this mode of movement economically unfeasible. In addition to the physical obstacles which would have to be overcome, the movement would cause severe traffic obstacles at every point along its route.

In addition to the difficulties described above, this means of movement would also represent an increased risk of accident. The chance of a vehicular accident is far greater than the possibility of a mishap by rail or waterborne trafíic. Accordingly, this alternative is not considered reasonable.

\subsection{ENVIRONMENTAL CONSEQUENCES}

The proposed off-loading activities that would take place on Federal land would be located at the SRS boat ramp on the Savannar River just upstream of SRS's TNX Area at river mile marker \#157. A recent Floodplain/Wetlands Assessment (see Appendix A) was conducted for the area surrounding the SRS boat ramp. This survey showed that the wetlands within the immediate area would not be affected by the offloading activities, providing that appropriate erosion control measures were implemented (Rogers, 1992).

The proposed actions would modify the existing 15 -foot wide ramp to accommodaie the 40-foot wide transport barge. The SRS boat ramp is shown in Figure 1. The CNSI modification activities at the SRS boat ramp are expected to be minimal in nature and have been reviewed and accepted by the U.S. Army Corps of Engineers (COE) as an action which is authorized under Nationwide Permit \#3 (COE, 1992; Appendix C). The modification activities would include dredging below the water line of the Savannah River on either side of the boat ramp skid plate; removal and trimming of overhanging flora on either side of the boat ramp; and the grading and clearing of the top of the boat ramp to lower the ramp's angle of descent. During the time frame between the two proposed SGSA trips, the area around the SRS boat ramp would be protected from the effects of erosion by the use of erosion mats.

In addition to the modification and environmental mitigation activities listed above, CNSI would also be responsible for returning the boat ramp above the orciinary high water mark to its preexisting condition. This would be accomplished by; re-paving the boat ramp with "crusher run" gravel; initiating continuing erosion prevention and control activities; and re-seeding the area surrounding the boat ramp. Also, during off-loading, additional environmental precautions would be taken, including the placement of a containment boom around the barge.

CNSI estimates approximately 17 cubic yards of sediment would be dredged from the area 20 feet on either side of the center line of the SRS boat ramp. This figure may vary once actual dredging has begun, as it is strongly tied to the level of the river at the time of construction. In order to maintain compliance with the COE nationwide permit, CNSI has stated that in no case would more than 25 cubic yards of material be removed from below the Savannah River ordinary high water mark. CNSI would dispose of all sediments and debris, after monitoring and sampling for contamination as necessary, on SRS in an SRS erosion control pit.

In addition to the dredging actions described above, it would be necessary to grade, scrape and reshape the top of the boat ramp (approximately 75 feet above the Savannah River waterline). This action would require the removal of the existing asphalt pavement and grading the top of hill to lower the overall angle of descent on the boat ramp. This surface grading is necessary to facilitate the off-loading of the SGSAs. Once the area in question had been graded to an appropriate level, it would then be re-paved with "crusher run" gravel to accommodate vehicular traffic, and all surrounding areas would be re-seeded and appropriate measures would be implemented to prevent erosion and sediment run-off. CNSI would dispose of all soil and debris from this area, after any monitoring and sampling for contamination, on SRS in an SRS erosion control pit.

The only other action associated with the boat ramp would be the clearing of overhanging trees on either side of the boat ramp. The trees in question would be cut down and/or trimmed to allow the CNSI off-loading crane access to the boat ramp. This action would be undertaken in such a manner as to ensure that the existing root system remained in place whenever possible. Once the off-loading of the SGSAs was completed, the area would be re-seeded and erosion control measures would be undertaken until such time 
as the banks of the boat ramp could be reestablished with floral growth. The timber to be cut in conjunction with this action is considered as "scrub" timber and is therefore not considered as marketable. There are no threatened or endangered species associated with this clearing activity.

This Federal action would not threaten a violation of applicable laws or regulations; nor require major expansion or construction of waste facilities such as storage, treatment, or disposal facilities; nor release hazardous substances, pollutants, or contaminants into the environment. This action would take place at an area on the Savannah River previously developed in the 1950s and would not adversely affect environmentally sensitive resources such as historical or archaeological sites, endangered species or their habitat. In addition, an existing programmatic memorandum of agreement with the South Carolina State Historic Preservation Officer describes how SRS cultural resources are to be managed and assessed to determine National Register eligibility. Activities related to this Federal action comply with this agreement.

One potential impact associated with the proposed action would be the possible erosion which could occur as a result of the clearing activities around the ramp. Accordingly, CNSI would abide by the Aiken County Erosion Control Ordinance and develop an approved Erosion Control Plan prior to construction activities beginning on the boat ramp. These plans typically call for the use of siltation fences, erosion control tarpaulins, and re-seeding to mitigate and control any erosion or sediment run-off. The cumulative effects of these activities have been reviewed and it was determined that they would have no major impact on the surrounding environment (USN, 1984 \& Rogers, 1992).

The construction and operation of a barge landing slip (an action similar to the one proposed in this EA, but on a larger scale) was previously assessed for the SRS boat landing, which includes the boat ramp, in the Environmental Impact Statement for the Disposal of Decommissioned, Defueled Naval Submarine Reactor Plants (USN, 1984). This EIS examined potential sites for the disposal of decommissioned, defueled naval submarine reactor plants. In doing this, it examined SRS and the area surrounding the SRS boat landing and ramp for impact on threatened and endangered species, wetlands, and other environmentally sensitive resources and found that such actions as are discussed in this EA would have "Temporary and minor environmental impacts.......". There has been no discernible change in the area surrounding the SRS boat ramp since the preparation of the EIS sited above.

The Final Environmental Impact Statement for the Continued Operation of K-, L-, and P. Reactors, ROEIS, (DOE, 1990), the Reactor Operation Environmental Information Documents, Volumes I-III (WSRC, 1989a, 1989b, \& 1989c), and the most recent socioeconomic survey of the sixcounty SRS area of influence (NUS, 1990) contain additional information on SRS areas and facilities, and the areas surrounding SRS. There has been no discernible change to the SRS since the preparation of the ROEIS.

\subsection{SAFETY IMPACTS}

The safety review for the SGSA shipping packages could be broken down into two parts. The first part would deal with conventional accidents arising from the off-loading activities to support the movement of the SGSAs, and the second with the nuclear safety issues associated with the off-loading activities to support the movement of these contaminated generator sub-assemblies.

\subsection{Conventional Safety}

Both of the safety issues discussed above have been reviewed by CNSI in the Safety Analysis Report (SAR) for Transport of Millstone Unit 2 Steam Generator Sub-Assemblies (See Appendix B), and by the NRC in the Safety Evaluation Report (SER) for Millstone Unit 2 Steam Generator Subassembly Package, Certificate of Compliance No. 9244, Rev. 0. A synopsis of the findings from this SAR and the SER are listed below. 
The conventional safety concerns associated with this SGSA movement would revolve primarily around the off-loading of the SGSA from the transport barge. The SGSA, trailer, and tow tractors weight of $1,150,350$ pounds increases the potential for an accident. However, the shipping contractor Lockwood Marine, Inc. is one of the nation's leading experts in the movement of oversized/overweight materials. The potential for an accident during the off-loading of the barge is minimal and all environmental and safety risks have been determined to be minimal in nature.

Once the SGSA was off-loaded it would be driven across the SRS to its final destination at the CNSI facility in Barnwell County. The affected section of each SRS road would be closed as required by the load position or as required to perform work to span the two bridges along the proposed route. SRS Road 3 would be closed for 6 hours and SRS Road 5 (Road 3 to Road 6) would be closed for 30 minutes. SRS Road 6 would be closed in sections: Road 5 to Road C for 45 minutes, Road C to Road F for 1 hour, and Road F to Road 7 for 45 minutes. Road 8 from Road 7 to the SRS boundary Williston Barricade would be closed for 6 hours on the second day of the move. Traffic signals at the barricades on SRS Road 3 near SC Highway 125 would be affected. The WSRC Electrical \& Instrumentation crews would be responsible for raising these lines. The SRS Power Department has also been notified about the pending move and would be in contact with South Carolina Electric \& Gas (SCE\&G) concerning their transmission line across SRS Road 6. SCE\&G would be responsible for raising these lines as the load approaches and lowering them after it passes.

In addition to the boat ramp modification, two SRS bridges, $603-8 \mathrm{G}$ and $603-43 \mathrm{G}$, would also be modified during each movement to meet the $116 \mathrm{ft}$ long, $18 \mathrm{ft}$ wide, $20 \mathrm{ft}$ high and 1,150,350 pounds truck-trailer combination capacity. All bridge modification would be done above the bridge, therefore, there would be no wetlands impacted during this modification. The actual load of the vehicle would never be placed on SRS bridges. As the load approaches the bridge, the contractor would construct the span using I-beams. After the load passes the bridge, the span would be removed and repair of any damage to the asphalt pavement would be corrected.

No damages are expected to occur to SRS bridges as a result of the movement of the SGSA. The transport trailers which would be used in conjunction with this movement are specially designed and constructed so that the weight of the SGSA is evenly distributed to the 168 wheels of the trailer and tow tractor. This load distribution should prohibit any damage. In the event that some damage does occur, CNSI has agreed to repair any damages. CNSI would coordinate with Wackenhut Securities, Inc.(WSI), the DOE contractor at SRS for security support services, for security and traffic control of the SGSAs while they are on Federal property. Close planning and coordination, including the movement of traffic signals and power would minimize any traffic effects as a result of the SGSA movement, thereby further minimizing traffic risks.

\subsection{Nuclear Safety}

In 1989, the Northeast Nuclear Energy Company performed a series of radiation dose rate measurements on contact with the top of the steam generator tube bundle. The dose rates at this location ranged from 7 to 15 $\mathrm{R} / \mathrm{hr}$. Contamination surveys were also taken inside the channel head. Each of the Sub-Assemblies is reported to contain approximately 1,403 curies of radioactivity. The major radioisotopes are Cobalt-60/58, Iron-55, and Nickel-63. The radioactivity is contained in a corrosion layer on the inside surfaces (primary side) of the tubes and channel head, and would be further contained by the injection of the concrete mentioned above. Trace amounts of fissile materials may be present. The Certificate of Compliance limits fissile materials to the exempt quantity defin'd in 10 CFR $\$ 71.53$. Therefore criticality is not a concern.

The application by Northeast Nuclear Energy Company to the Nuclear Regulatory Commission was approved June 3, 1992 and constitutes authority to use the package for shipment of radioactive material and for the package to be shipped in accordance with the provisions of 49 CFR 173.471.

The Northeast Nuclear Energy Company and the NRC performed independent analysis, using MICROSHIELD, to calculate the external dose rate from the SGSA. Table 1 summarizes these results. 
Table 1

Summary of External Dose Rates

\begin{tabular}{cccc}
\hline \hline SGSA Location & NNEC (mrem/hr) & NRC (mrem/hr) & Allowable (mrem/hr) \\
\hline \hline Package Surface & & & \\
Side & 64.1 & 66.7 & 200 \\
Top & 94.2 & 114.6 & 200 \\
Bottom & 4.0 & $-\cdots$ & 200 \\
Meters from Surface & & & \\
Side & 31.1 & 31.6 & 10 \\
Top & 11.4 & 10.7 & 10 \\
Bottom & 0.3 & $-\cdots$ & 10 \\
2 Meters from Barge & & & 10 \\
Side & 11.5 & 11.5 & 10 \\
Top & 1.8 & $-\cdots$ & 10 \\
Bottom & 0.04 & $-\cdots$ &
\end{tabular}

* 2 meters from package surface for side dose rates, 2 meters from edge of trailer for top and bottom dose rates.

In order for the SGSAs surface dose rates to be in compliance with 10 CFR $\$ 71.47$, CNSI would be required to weld on additional shielding to the surface of the package. In addition to the shielding, CNSI would undertake the following additionai safety precautions prior to shipment of the SGSAs from Millstone;

- A CNSI Health Physic technician would accompany the SGSA movements.

- Radiation measurements would be taken to ensure that the radioactivity is not significantly different from the estimates on the NRC application and that the contents meet the concentration limits for low specific activity material.

- Visual inspection of all closure plates and welds.

- External radiation measurements which show that the package meets the standards of 10 CFR $\$ 71.47$.

- Contamination surveys which show that the package meets the standards in 10 CFR $\$ 71.87$.

The contents being moved qualify as Low Specific Activity, therefore, the package has been evaluated for the Normal Conditions of Transport as defined in 10 CFR Part 71. The specific section of 10 CFR Part 71 are 10 CFR Part 71.40(b), (c), and (d). The application by Northeast Nuclear Energy Company to the Nuclear Regulatory Commission was approved June 3, 1992 (NRC, 1992). Authorization has been requested and received from $\mathrm{NKC}$ to ship the two packages, each for a one-time, single-trip shipment between the Millstone site in Waterford, and the disposal facility near Barnwell.

The preparation of the Millstone Unit 2 SGSAs, as described above, would result in a radiologically sound package which meets the requirements for a structurally sound Type A packaging for shipment of radioactive material. The package is expecied to retain the containment integrity of its radioactive contents when subjected to the Normal Conditions of Transport as defined in 10 CFR 71. 


\subsection{REFERENCES}

COE (U.S. Army Corps of Engineers), 1992. Letter dated August 13, 1992. Nationwide Permit \#3. Repair, Rehabilitate or Replace a Currently Serviceable Boat Ramp, Charleston District, Charleston, South Carolina

CNSI (Chem-Nuclear Systems Incorporated), 1991. Report dated December 1991. Safety Analysis Report for Transport of Millstone Unit 2 Steam Generator Sub-Assemblies, CNSI, Columbia, South Carolina

DOE (U. S. Department of Energy), 1990. Final Environmental Impact Statement, Continued Operation of K-, L-, and P-Reactors, Savannah River Site, DOE/EIS-0147, Savannah River Operations Office, Aiken, South Carolina.

DOE (U. S. Department of Energy), 1991. Intent to Prepare Programmatic Environmental Impact Statement for Reconfiguration of the Nuclear Weapons Complex, Federal Register 56 FR 5590-5596

NRC (U. S. Nuclear Regulatory Commission), 1992. Certificate of Compliance No. 9244 for Radioactive Materials Packages (Model No. Millstone Unit 2 Steam Generator Subassembly package) and Safety Evaluation Report. Dated June 3, 1992. Nuclear Regulatory Commission, Washington D.C.

NUS (NUS Corporation), 1990. Socioeconomic Characteristics of Selected Counties and Communities Adjacent to the Savannah River Site, NUS Report No. 5234, Savannah River Center, Aiken, South Carolina.

Rogers, V., 1992 Memorandum to P. Harmon, September 18, 1992. Evaluation of Wetland Near SRS Boat Ramp, SRT-ESS-92-0529, Westinghouse Savannah River Company, Aiken, South Carolina.

USN (U.S. Department of the Navy), 1984. Final Environmental Impact Statement, Disposal of Decommissioned, Defueled Naval Submarine Reactor Plants, United States Department of the Navy, Washington, D.C.

WSRC (Westinghouse Savannah River Company), 1989a. Reactor Operation Environmental Information Document, Volume I: Geology, Seismology and Subsurface Hydrology (U), WSRC-89-815 Savannah River Site, Aiken, South Carolina.

WSRC (Westinghouse Savannah River Company), 1989b. Reactor Operation Environmental Information Document, Volume II: Ecology (U), WSRC-89-816 Savannah River Site, Aiken, South Carolina.

WSRC (Westinghouse Savannah River Company), 1989c. Reactor Operation Environmental Information Document, Volume III: Meteorology, Surface Hydrology, Transport and Impacts (U), WSRC-89-817, Savannah River Site, Aiken, South Carolina. 
APPENDIX A: Floodplain/Wetlands Assessment 
Floodplain/Wetlands Assessment

for

DOE Permission for Off-Loading Activities to Support the Movement of Millstone

Unit 2 Steam Generator Sub-Assemblies Across the Savannah River Site (SRS)

\subsection{DESCRIPTION OF PROJECT}

This Floodplain/Wetlands Assessment is designed and intended to function as an Appendix to the Environmental Assessment for DOE Permission for Off-Loading Activities to Support the Movement of Millstone Unit II Steam Generator SubAssemblies Across the Savannah River Site (DOE/EA-0818). As such a detailed description of the proposed action may be found in that document.

\subsection{EFFECT ON FLOODPLAINS OR WETLANDS}

\subsection{Floodplain Assessment}

The proposed site to be reviewed under this Floodplain/Wetlands Assessment is in a well drained floodplain of the Savannah River. The site is currently serving in the capacity of an established and operating boat ramp on the South Carolina side of the Savannah River. The proposed site which is subject to this assessment is a government owned and operated plot of land on the Savannah River Site (SRS). Accordingly modification of this site, as described in the EA, represents no potential effect on the lives or property of the local populace.

Modification of the SRS boat ramp will result in the loss of a few bottom land hardwood trees. This is considered as an acceptable loss as the species involved with this clearing activity are considered as "scrub" timber with no commercial value. There are no threatened or endangered species involved with this activity. The overall benefit of this activity will be to improve the quality, accessibility and safety of the existing boat ramp. By re-planting and re-seeding the area with desired replacement species, the esthetic value and long term viability of the site will actually be improved.

A potential negative aspect of the proposed action is the possibility of erosion from excessive rains or high river flow during the proposed activity. This potential risk may be reduced by installing pilings at the water line of the boat ramp where the cutting edge of the Savannah River bends inward towards the ramp. The soil material at the subject location is classified as Udorthents, which was formed during construction of the Ellenton Dock and the present boat ramp from Shellbluff and Tawcaw soil series. These soils are typically developed in the well drained floodplains of this region. These soils are normally deposited by streams, and are therefore very erosive in nature. Special precautions are needed during the disturbance of the vegetative cover in this area. Some of the erosive potential may be reduced by diverting run-off water away from the newly constructed area, by using mulch and matting, and by re-seeding immediately after completion of the grading.

\subsection{Wetlands Assessment}

There would be no impact on the surrounding wetlands as a result of the proposed action. There are no wetlands adjacent to the road leading out of the river (boat ramp), therefore 
no direct impact to wetlands should occur. There are wetlands about 400 feet north-east of the rivers edge (and the proposed action). To protect this area, a ridge (a compressed soil berm) should be left between the proposed activity and the wetlands after the grading is completed. This will prevent the creation of a new outfall which may inadvertently drain the wetlands. This soil ridge would also serve to reduce the erosion potential associated with this activity.

\subsection{Positive and iregative Effects}

The only foreseeable negative impact associated with this project is short term in nature. The possibility of sediment run-off, or erosion, which could occur as the result of a storm during the construction period, has the potential to result in a temporary localized reduction in the water quality of the Savannah River. This erosion could also inflict some minor damage to the soils along the bank in the proposed area.

The overall result of the proposed activity would be beneficial in nature. The project would provide the SRS with an improved landing facility which could accommodate broader spectrum of waterborne equipment. This project also has the potential to improve the overall beauty and long te:m viability of the area through selective reseeding with more desirable species.

\subsection{ALTERNATIVES CONSIDERED}

Alternatives to the proposed action and mitigating measures to prevent damage to the proposed site are covered in Environmental Assessment for DOE Permission for OffLoading Activities to Support the Movement of Millstone Unit II Steam Generator Sub-Assemblies Across the Savannah River Site. 
APPENDIX B: NRC Certification and Safety Evaluation Report 


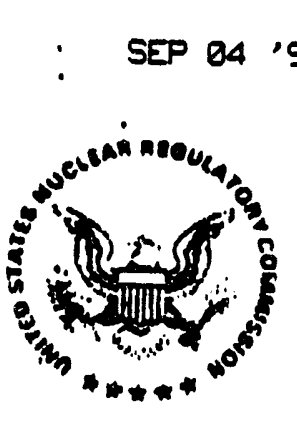

11:24AM CNSI COLA INMINEERIN

P. 4

\author{
UNITEO STATEB \\ NUCLEAR REQULATORY COMMISSION \\ WAOHINOTON, D.C. 20:S
}

SAFETY EVALUATION REPORT

M1llstone Unit 2 Steam Generator Subassembly Package

Certiflcate of Compliance No. 9244

Revision No. 0

\title{
SUMMARY
}

By application dated December 23, 1991, as supplemented, Northeast Ut II it les requested approval of the MIllstone Unit 2 Stoam Generator Subassembly as a aetfvity radioactive matortal. contained in the application and the upon the statoments and roprasentatiols concluded thet the Millston and the conditfons 11sted below, we have the requiraments of 10 CFR Part 71 . Stean Generator Subassembly package neets

\section{REFERENCES}

Northeast Utilities application dated December 23, 1991.

Supplements dated: Aprfl 30, and May 18 and 27, 1992.

\section{DESCRIPTION}

A stean generator sibasscmbly fllled with low densfty concrete. The steam primary channel hoad. The stean goverator subassembly is essentially of $16^{\prime} 8-3 / 4^{\prime \prime}$ at an 00 of $13^{\prime} 9^{\prime \prime}$ along the tube bundle region and a maximum 00 A516 and A533 carbon steel. wall. and 5-5/8" In the transitton wall thickness varies from 4-3/8" in the side tube bundle ts composed of 8518 on rogion, to $7^{n}$ in the channel head. The $O D$ of $0.75^{\prime \prime}$ and wall thickness of $0.048^{\prime}$ and tubes, which have an epproximate thick tube support plate. The top of the and which are positioned in a $21^{n}$ closed by way of a steel "top hat" assembly steam generator subassembiy is generator shell. The lenoth of the steam approximately 41' 11-1/2". Nozzles and generator subassembly package is welded closures. The steam generator subagsen penotrations are covered with conerete on both primary and secondery subassembly is fllled with low density approximately 420 tons.

Figure 1 is a sketch of the package. Figure 2 is a representation of the package loaded onto the motor vehtcle and on the barge. 


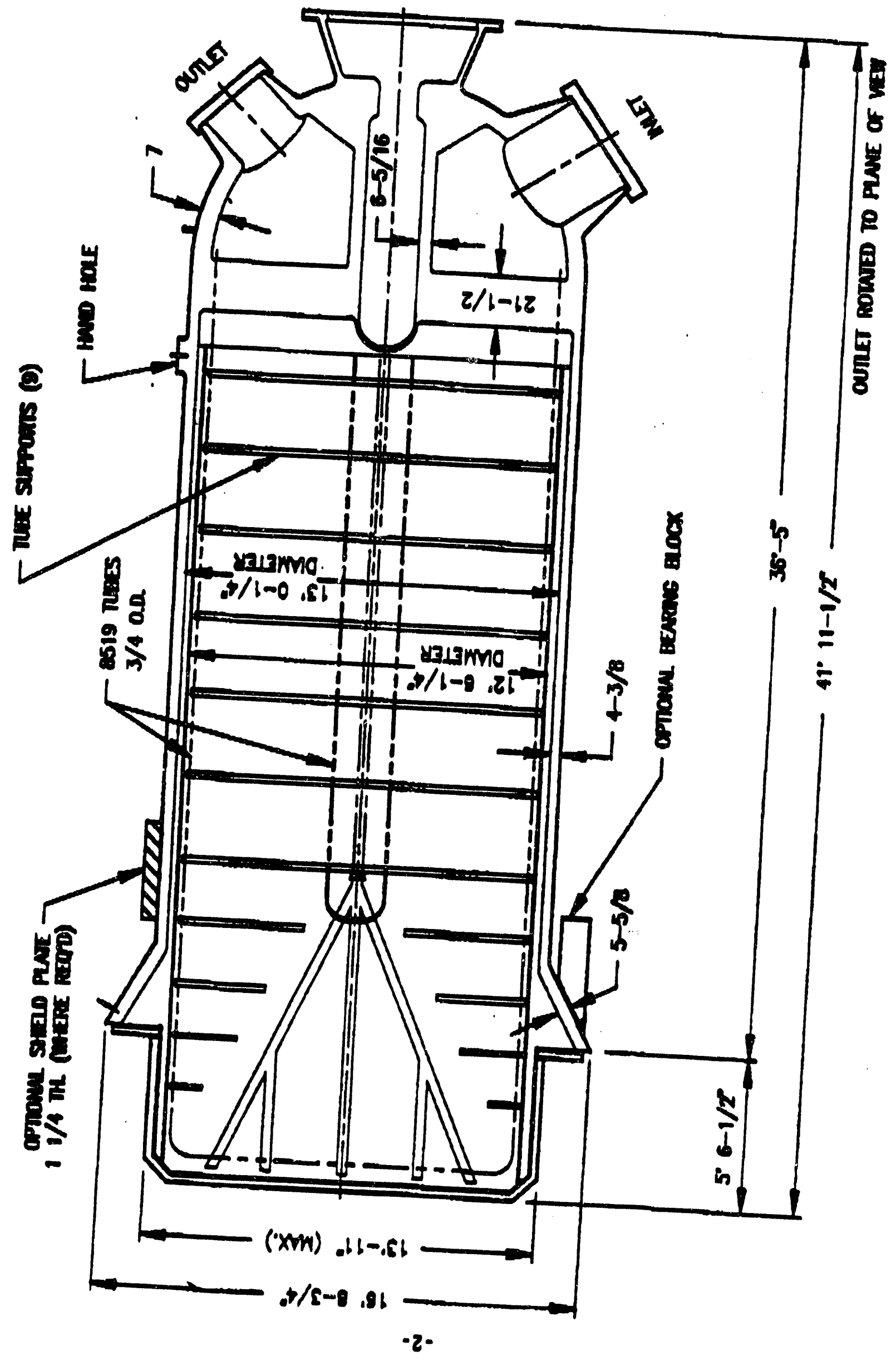



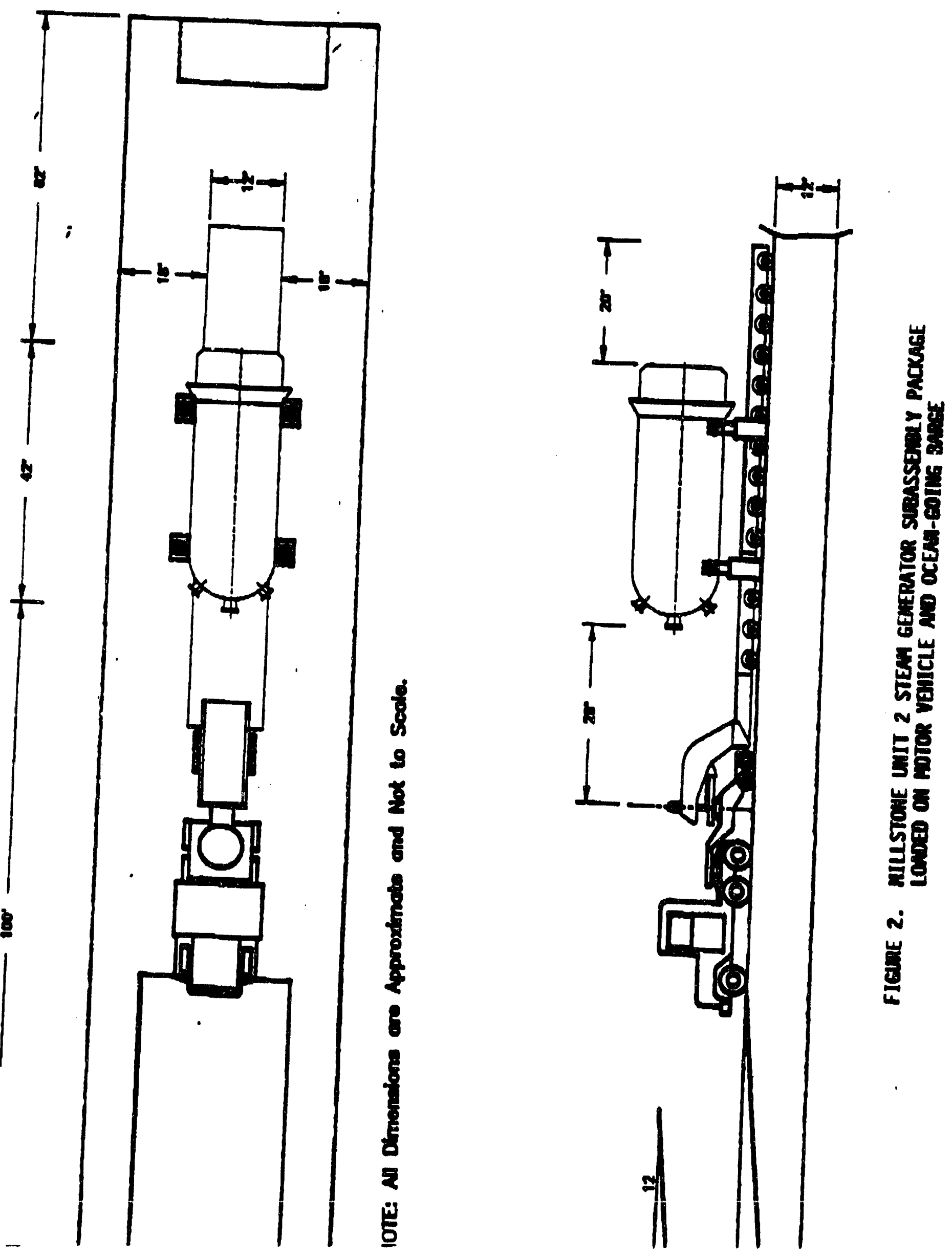


\section{DRAWINGS}

The package is constructed and assambied in accordance with the following Chem-Nuclear Systems, Inc. Drawing Nos:

$$
\begin{aligned}
& C-110-B-43211-1, \text { Rev. I } \\
& C-110-A-43211-2, \text { Rev. I } \\
& C-110-0-43211-3, \text { Rev. I } \\
& C-110-B-43211-4, \text { Rev. }
\end{aligned}
$$

\section{conTENTS}

A. Type and form of material

Steum generator subassombly containing radioactive contamination, filled with low density corcrete, meoting the requirements of low speclfic activity radioactive material.

B. Maximum quantity of material per package

Greater than a Type A quantity of radioactive material. Fisslie material may be present provided the fissile material does not exceed the mass IIntts of 10 CFR 871.53 .

\section{STRUCTURAL EVALUATION}

The steam ganerator subassembly package contains greater than a Type A quantity of low specifle activity radfoactive antertal. Consequentiy, the structural evaluation of the package design must demonstrate that the deston meets the perfomance requirements of 10 CFR Part 71 for normal canditions of transport.

\section{A. General standirds for all Praknaes}

\section{Hintmin Praknge sian.}

The package meets the requirements of 10 CFR $571.43(2)$ for minimum size.

Inmoer-progf Fenture

The package requires no tamper-proof feature bacause the packege top b and the nozzle closure plates are welded to the vessel. 


\section{Positive Closume}

The package cannot be inadvertently opened because the closures of the package are all wolded shut.

\section{Chemiarl ind Grlynnta Berations}

The materfals used in the package will have no significant chemical, gaivanic and other ractions.

\section{Vuluns or Othar Daviass}

There are no valves or othar devices on the package.

B. Lettine and Tleadoun Stendned For all enaknon

\section{Wifting Daviens}

There are no machanical or wilded attachmants to the package that can be used in lifting the puckage during transport. The top hat lugs are rendered inoperable for package lifting and tle-down.

\section{Ife-Doim Dentaes}

The staif review did not include the equipment or the mothod used to support the package or to t1e the package down to the trafler or to the barge. This is because there am no tle-down devices that are a structural part of the packago, and the t10-down standards of 10 CFR part 71 do not apply.

The applfeant designed the package tfo-down system to withstand the loads specteled in ANSI N14.24. For the barge phase of the transport, stresses in the tie-down system will be 11mited to the allowable strass values spectfted in the AIsC codo. For the land transport phase, the allowable strasses in ANSI N14.24 will be used.

To ensure the adequacy of the support and t10-down system, and to ensure that the support and t10-down system recofves the propor review, the Certificate of complfance has been condittoned to spectfy that the system used to support and tie the package down be roviewed and certified by the Katlonal Cargo Buroau, Inc. The Natfonal Cargo Bureau Is authorized in 49 CFR 8176.18 to assist the Coust Guard in inspecting the stowage of hazardous materlals and in cortifying that the stownge of hazardous matortals on vesseis is in eccordance with 49 CFR subtitle B, 
Chapter I, Subchaptar C--Hazardous Materials Regulations. In addition, the Certiffeate of Compliance has been conditioned to specify that the shipment be inspected by the Coast Guard prtor to transport to ensure proper stowage of the package on the barge.

\section{Normal Condittons of Iransport}

\section{Hent}

There will be no signiflcant prassure bulldup or stress increase in the vessel under the normal transport heat condition.

Cold

The applicant performed a stress analysis of the package at $-40 \%$. The calculated stresses were well within allowable values.

The primary materials of construction of the containwent vessel are SA508, Class 1 and 2, SA516 Grade 70, and SA533 Grade B, Class 1. These materlals were evaluated for brittle fracture. The rasults showed that the materials meet the fracture toughness criterie of Regulatory Guide 7.11 for Category III containers. Regulatory Guide 7.11 provides fracture toughness criteria for Category I, II and III containers with shells up to $4^{\prime \prime}$ thick. The thickness of the steam generator shell is 4 3/8" along the side wall, 5-5/8" in the transition reglon, and $7 "$ in the channel head. The NRC does not have fracture toughness criterla for Category III vessels greater than 4" thick. Howevor, since the fabrication methods for the steam generator vassel wore in accordance with ASME, Section III, Diviston I, for nuclear components, and exceed the criteria for 4"-thick Category III transportation packages, the staff agrees that the brittie fructure evaluation using the criteria of Regulatory Gutde 7.11 is accoptabla.

\section{Reduced External Pressure ind Increased External Pressure}

The applicant evaluated the effects of an external pressure of 3.5 psia. Results of a fintte element analysis using the. WSYS computer coda, showed that the maximum stresses in the top hat were woll below the allowable primary stresses.

To evaluate the offects of an increased external pressure of 20 psta, the vessel was conservatively ovaluated for the more critical case of an Increased external pressure of 21.67 psig (e.g., 50 feet water immersion). The evaluation showed that stresses in the vessel were well below the allowable stresses. 


\section{Shock and vibration}

There are no valves or other devices on the container that are susceptible to shock and vibration loads. Also, the contalnment vessel is fllled with low density conerete to fix the contents in place. The tle-down system will be revlewed, approved, and certifled by the National Cargo Bureau, Inc. as meeting the requirements of DOT regulations. There will be no signifteant adverse effects on the containment vessel, or its contents, from the shock and vibration loads normally incident to transport.

\section{Weter Sorny}

The container is of welded steel construction. Water spray will have no effect on the containor.

\section{Eren Dros}

Due to the very large size and weight of the package, and considering the spectal handling and operational controls, a one-foot free drop would not be a normal condition of transport. The package is loaded onto a wheeled vehtcle, which is driven onto a barge at the applicant's site. Once loaded onte the vehicle, the package is not lifted uitfl it is removed from the vehiclo at the disposal site. The transport is primarlly by barge, with only a short highway leg, much of which is on the DOE Savannah River site. The applleant is taking special precautions to ensure the safe shipment of the packages. These special precautions are 11sted in Chapter 7 of the application and are summarized in Table 1.1 of the application. These precautions will be conditions of approval in the NRC Certifleate of Compliance. In addition, the Cortiflcate of Compliance spectefos that the approval is limited to a ono-time shipment of two separate packages. Although the applicant provided a structural analysis of the one-foot free drop. for the reasons stated above, the staff did not consider the analysis in its raviow.

\section{Corner Dros}

This test is not applicable because the wolght of the package exceede 200 pounds and notther wood nor fiber board is used as a material $r$ construction.

\section{Comoresston}

This test is not applicable because the woight of the pact 11,000 pounds. 


\section{Penatration}

A 13-pound steel eylinder dropped from a height of 40 inches would not penetrate the contafnment vessel.

D. Concluston

The applicant has evaluated the paekage for the normal conditions tests spectfled in 10 CFR 571.71, excluding the one-foot free drop. In accordance with 10 CFR $871.41(\mathrm{C})$, the staff agrees that the controls proposed to be exerctsed by the shippor are adequate to assure the safaty of the shipaent, and that the one-foot free drop would not be a norwal condition of transport for this package. The staff agrees with the applicant's conclustons that the package has suffictent structurel integrity to meat the applirable performance criterta in 10 CFR Part 71.

THERMAL

The decay heat in the package is negligible.

\section{CONTAINMENT}

The contalnment vessel boundary is dofined as the steam gonerator sholl, the nozzlo closures, and the top hat assembly. The containment vessel is welded closed. Vold spaces within the vessel are flllod with low density concrete. The containment vessel will remain intact under the normal conditions of transport as deserfbed above, and there w1ll be no loss or dispersal of radfoactive matertal.

\section{EVALUATION OF RADIOACTIVE CONTENTS AND SHIELDING}

The radioactivity present in the package is in the form of a tightly adherent contamination layer of activated corrosion products on the primary side surfaces of the steam generator subassembly (inside of the tubes and the primary channel head). The applicant estimated the radioactivity present in the package and the external dose rates based on radiation and contamination surveys performed whlle the steam generator was operational. 


\section{A. Badleactive Contents}

In 1989, the applicant performed a sarfes of radiation dose rate measurements on contact wtth the top of the steam generator tube bundle. The dose rates at this location ranged from 7 to $15 \mathrm{R} / \mathrm{hr}$. Contamination surveys were also taken inside the channel head. The isotopic distribution was based on these contanination surveys.

The radloactivity present in the package was calculated using two computar codes, ISOTOPE Varsion 83.3 and QAD Verston 79.0. ISOTOPE determined the gamma spectrum used as input in QAD, using seven onorgy groups. The gamma spectrum was based on an input of one curle. The QAD computer code was used to caleulate the dose rate at the top of the tube bundle based on the ISOTOPE input. The curfe content of the package was derfved by nomalizing the calculated dose rate to the maximum dose rate masured on the tube bundle (15 R/hr).

The total radioactivity was estimated at 1403 curles. The prodominant gamma emitting nuclides were cobait-60 (442 curles) and cobalt-58 (330 curles). Fisslie materlals were present in trace quantities, but were well below the fissile exempt quantities of 10 CFR 571.53 . The staff agrees that the applicant's source term is conservative.

The staff performed a confirmatory anaiysis, using the applleant's values for the measured dose rate and the isotopic distribution, and using MICROSHIELD, point karnel computer code. The staff's results wore consistent with the applicant's.

Using the calculated source terms, the applicant determined the concentration of radiouctivity in the package. Considering oniy the weight of the low-density concrete, the concentration of radloactivity was approximately $0.036 \mathrm{mCl} / \mathrm{g}$. The woight of the steam generator tubes, shroud, and shell was conservativaly ignored in determining the concentration of radioactivity. The contents of the package moet the IImits for low speciftc activity radioactive material defined in 10 CFR 871. 4.

\section{B. Shielding Calculation}

The results of the contents analysis were used to estimate the external dose rates for the package. The components of the package included in the shielding analysis were the tubes, low density concrete 10.336 $\left.\mathrm{g} / \mathrm{cin}^{3}\right)$, air, and ouser steel wall. The tubes, atr and low density concrete inside the shroud were homogentzed and modeled at the 
appropriate effective density. The concrate outside the shroud and the nuter steel wall were modeled as concentric cylinders. No shielding cridit was taken for the concrete inside the tubes.

The appliteant used MICROSHIELD to calculate the dose rates at the package surface, at 2 meters from the package zurface, and at 2 meters from the edge of the conveyance. The results showed that the dose rates at the package surface were within 10 CFR $\$ 71.47$ limits, but the 2 meter dose races were not. The applicant has conservatively estimated the external dose rates, and the measured dose rates are expectad to be lower than the calculated values. However, the applicant will weld additional shielding on the surface of the package as necessary to comply with the radiation standards in 10 CFR 573.47.

The NRC staff perforwad an independent anelysis, using MICROSHIELO, to conftrm the applicant's results. The table below summarizes the results of the appilcant's and staff's analyses.

EXTERNAL DOSE RATES (mrem/hr)
Lecation ADPlieant NRC Allomable

Package surface

$\begin{array}{lrcc}\text { Side } & 64.1 & 66.7 & 200 \\ \text { Top } & 94.2 & 114.6 & 200 \\ \text { Bottom } & 4.0 & \ldots . . & 200\end{array}$

2 Metors from surface*

$\begin{array}{lrrr}\text { Side } & 31.1 & 31.6 & 10 \\ \text { Top } & 11.4 & 10.7 & 10 \\ \text { Bottom } & 0.3 & \ldots . . & 10\end{array}$

2 Meters from barge

$\begin{array}{lccc}\text { Side } & 11.5 & 11.5 & 10 \\ \text { Top } & 1.8 & \ldots \ldots & 10 \\ \text { Botton } & 0.04 & \ldots . . & 10\end{array}$

- 2 meters from package surface for side dose rates, 2 meters from edge of tratler for top and bottom dose rates.

The applicant intends to add shielding, as necessary, to meet the radiation standards in 10 CFR 571.47. The need for shtelding will bo determined based on measurements taken prlor to transport. The Certiflcate of Compliance has been conditioned to spectfy that shielding must be welded to the surface of the package, as necessary, to meet the external radiation standards of 10 CFR 571.47. 


\section{CRITICALITY}

Trace amounts of fisstle materials may be present. The Certificate of Compliance limits fissile materials to the exempt quantity defined in 10 CFR
\$71.53. Therefore criticality is not a concern.

\section{FABRICATION EVALUATION}

The Millstone Untt

generators were fabricated in accordance w1th the are acceptable for a Category lil components. These fabrication criterla made and inspected according to the Asueortation package. Now welds w111 bo drawings reforanced in the Cortiffcate code as spectffed on the paekaging

\section{OPERATING PROCEDURES, ACCEPTANCE TESTS AND MAINTENANCE PROGRAM} The two steam generator subassembly packages will be prepared for shipment
from the Millstone Power Plant site for disposal near Barnwell, south
Carol ina. Each package will be shipped separatel Carolina. Each package will be shipped separately. Each package will be onto an oce a traller designed for heavy loads, and the traller will be driven and into the savannah River. The barge wlll be transported along the east coast road before reaching the disposal site. Chapter 8 of the application describes the acceptance tests which w111 bo radiation measurements which to transport. These tests include: significantly different than the est imates the radioactivity is not contents meet the concentration limits for in the application, and that the visual inspection of the closure plats for low specific activity material, measurements which show the package ates and welds, (3) external radiation 671.87.

Chapter 7 of the application describes the operational used during transport of the packages. 
Some of the operational controls during the barge phase are: (1) the use of a pre-planned route, (2) the use of an escort tug to accompany the primary tug, (3) a health physics technictan present on the tug, (4) dual radar and dual navigational aids on the primary and escort tugs, (5) communication with tho base station at least every four hours, (6) a maximum speed of transport of 10 knots.

Some of the operational controls during the tratier phase are: (1) a maximum transport speed of $5 \mathrm{mph},(2)$ escorts provided to control trafflc near the traller, (3) crossing roads blocked off whllo the traller is passing through intersections.

Prior to transport, each shipment will recelve trip-in-tow inspection performed by a qualifled marthe surveyor. The Certifleate of Compliance has been condftioned to spectfy that after the package is loadod onto the barge, the National Cargo Bureau, Inc. Will inspect and certify that the system used to support and tio down the package to the barge and the stowage of the pacisage are in accordance with the regulations of the Colimandant. United States Coast Guard. In addttion, the U.S. Coast Guard will be notifled of the shipment and will inspect the condition of the vassel and the stowage of the package on the barge prior to transport.

\section{CONOITIONS}

1. In addition to the requirements of Subpart $G$ of 10 CFR Part 71:

a. The package must be prepared for shipment and transported in accordance with Chapters 7 and 8 of the application.

b. The package must be transported in accordance with the operational controls of Table 1.1 of the application.

c. The top hat lugs are rendered inoperable for package iffting and t1a-down.

d. Prior to transport, shielding must bo weided onto the package in accordance with Chem-Nuclear Systems, Inc. Drawing No. C-110-8-43211-1, Rev. 1, as necessary, such that the package meets the external radiation standards of 10 CFR 571.47.

2. Prior to transport, the National Cargo Bureau, Inc. must havo ovaluated the system used to support and tle down the package on the barge, and must have certiffed that the support and tle-down system and the package stowage is in accordance with the ragulations of the Commandant, Unitar States Coast cuard. 
3. Prior to transport, the United States Coast Guard must have inspected the condition of the vessel and the stowage of the package on the barge.

4. This cortiffeate authorizes a one-time shipment for each of two packages from the Millstone Nuclear Power Plant site to a point near Barnwoll.

3. The package authorlzed by this certificate must be transperitod on a motor vehicle and on a seagoing vessel assigned for sole use of the 6. The package authorized by this certificate is horeby approved for use
under the genoral license provistons of 10 CFR 571.12 .

7. Expiration date: May 31, 1997.

\section{CONCLUSIONS}

Besat on the review of the statements and representations contained in the application, as supplemented, and the conditions listed above, wo have concluded that the M111stone Unit 2 Steam Generator Subassembiy package meets
the requitranents of 10 CFR Part 71 .

Dato

Max $r$ : m:

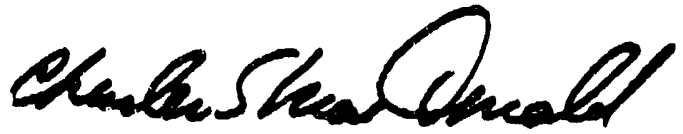

Charles E. Macoonald, Chief

Transportation Branch

Division of Safoguards and Transpartation, Muss 
APPENDIX C: COE Nationwide Permit 


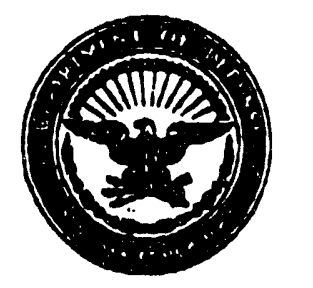

DEPARTMENT OF THE ARMY

CMAALETON DISTA:CT COAPS OF ENOINEEAS

- o dox 010

acesico

CMAMLEATON. $\&$ C 204020010

arrenicion os

August 13,1992

Regulatory Branch

Lockwood Brothers, Inc.

Attn: Mr. Robert Phililips

220 Salters Creek Road

Hampton, Virginia 23659

Dear Mr. Phlllitps:

This is in response to your latter dated August 7, 1992, wherein you requested permission to repair, rehabliftate, or replace a currently serviceable boat ramp at intle post 1157 on the Savannah RIver in Barnwell County, South Carolina.

This is to inform you that the proposed work is authorized by a nationwide permit since it is considered to be the repalr, rehabilitation, or replacement of a previously authorized, currently serviceable structure. This work is authorized provided such repair is not put to uses differing for those speclffed for it in any permit or modification authortzing its original construction. Authorization of this work is subject to the attached spectal conditions and the IImitations specified herein.

In addition, you indicated that some minor dredging may be necessary to accomplish the planned work. Such minor dredging is authorized by Natlonwide

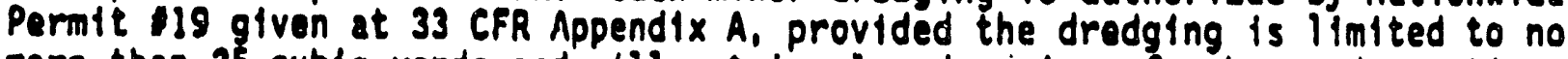
more than 25 cuble yards and will not tnvolve dreijing of submerged aquattc vegetation, anadromous fish spawning areas, or wetiands. If the work requires dredging of more than 25 cublc yards or involves dredging of submerged aquatic vegetation, anadromous fish spawning areas, or wetlands, then an individual

Department of the Army permit will bo required.

In future correspondence concerning this mattor, please refor to SAC-03-92-655-X. You may still need State or local assent. Prior to performing any work, you should contact the South Carolina Water Resources Commission. A copy of this letter is being forwarded to them and the Environmental Protoction Agency for their information. The addresses for these agencles are provided on the enclosed ifst for your conventence.

This authorization is valid unt1l January 21, 1997. The time spectfled for this authorization will remain valid if the nationwide permit is raissued without modification, or the activity complies with any subsequent modification; however, the provistons of 33 CFR $330.6(\mathrm{~b})$ will apply if the natlonwlde permit expires, is suspended or revoked, or is modifled such that the activity no longer complies with the orlatagt 
general these provisions provide that if the work authorized by this letter has commenced in accordance with the requisite terms and conditions or you, acting in rellance of this natfonwide permit, have entered into a contract to have the work performed prior to such date, this authortzation will remain in effect if the work can be completed within twelve months of the date of the nat lonwide permit expiration, modification or revocation unless discretionary authorfty has been exercised in accordance with 33 CFR $330.4(c)$ or (d).

If you have any questions concerning this matter, please contact mo at AVC $803-727 \cdot 4330$.

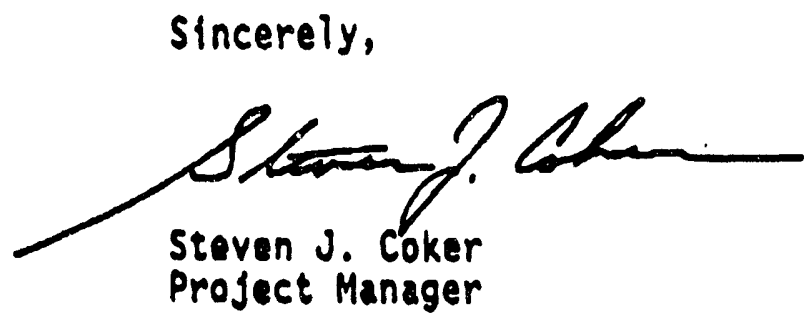

Enclosures

Copy Furnished:

Mr. Joe Dennts

South Carolina Water Resources Commission

1201 Main Street, Sulte 1100

Columbia, South Carolina 29201

U. S. Environmental Protection Agency

Region IV, Wetlands Regulatory Unit

345 Courti and Street

Atlanta, Georgia 30365 


\section{U.S. DEPARTMENT OF ENERGY \\ FINDING OF NO SIGNIFICANT IMPACT \\ DOE PERMISSION FOR OFF-LOADING ACTIVITIES TO SUPPORT \\ THE MOVEMENT OF MILLSTONE UNIT 2 STEAM GENERATOR SUB-ASSEMBLIES ACROSS THE SAVANNAH RIVER SITE, AIKEN, SC}

AGENCY: Department of Energy

ACTION: Finding of No Significant Impact

SUMMARY: The Department of Energy (DOE) has prepared an Environmental Assessment (EA), DOE/EA-0818, for the proposed granting of DOE permission of offloading activities to support the novement of Millstone Unit 2 steam generator sub-assemblies (SGSAs) across the Savannah River Site (SRS). Based on the analyses in the EA, DOE has determined that the proposed action is not a major Federai action signiflcantly affecting the quality of the human environment within the meaning of the National Environmental Policy Art (NFPA) of 1969. Therefore, an environmental impact statement is not required, and the Department is issuing this Finding of No Significant Impact (FONSI).

On ti:e basis of the floodplain/wetlands assessment in the EA, DOE has determined that there is no practicable alternative to the proposed activities and that the proposed action has been designed to minimize potential harm to or within the floodplain of the SRS boat raing. No wetlands on SRS would be affected by the proposed ar:tors.

\section{MASTER}

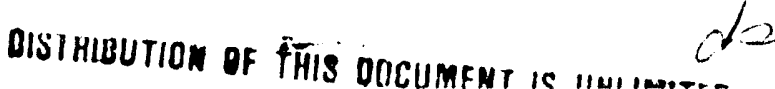




\section{PUBLIC AVAILABILITY:}

Copies of the EA and FONSI are available from:

Mr. Karl E. Goodwin

U. S. Department of Energy

Office of Processing and Reactor Facilities

1000 independence Avenue, S.W.

Washington, DC 20545

Phone: (301) 903-5498

For further information on the NEPA process, contact:

Ms. Carol Borgstrom

U. S. Department of Energy

Office of NEPA Oversight

1000 Independence Avenue, S.W.

Washington, DC 20545

Phone: (202) 586-4600 or (800) 472-2756.

BACKGROUND: The Millstone Unit 2 in Waterford, Connecticut, is retiring its two steam generators. As approved by the Nuclear Regulatory Conunission (NRC), the two decommissioned SGSAs would be seal-welded, filled with concrete, and moved to the CNSI facility located in Barnweli County, South Carolina for disposal as lowJevel radinactive waste. Each SGSA package would consist of a steam generator vessel, top hat, tubes, tube supports and concrete, and would have a total radioactivity calculated at 1403 curies. Tre major radionuclides are Cobalt-60/58, Iron-55, and Nickel-63. Each SGSA package would be loaded on a trailer and then on to a barge in Connecticut and moved to CNSI separately. The loaded truck-trailer combination would be 116 feet long, 18 feet wide, 20 feet high, and weigh 1,150,350 pounds. The loaded barge would be approximateiy 200 feet long and 40 feet wide, draw 4 feet of water, and be pushed by two tugboats. 
PROPOSED ACTION: The proposed action is for DOE to grant permission to Chem-Nuclear systems Incorporated (CNSI) to modify and use the SRS boat ramp at river mile 157 on the Savannah River to facilitate offloading and movement of two SGSAs over SRs roads for their disposal at the CNSI low-level radioactive waste burial facility. Two separate trips would be necessary.

Federal permission to use the SRS boat ramp is necessary to enable CNSI to ship the two SGSAs via waterborne traffic, the safest and most economical means of movement for these huge packages. Once offloaded, the SGSAs would be moved across SRS using CNSI equipment to the CNSI facility. The proposed action has no connection to SRS operations and is in no way necessary to support SRS activities.

AdTERIJAfrVES: In addjtion to the proposed action, DOE considered the rc a:tion aiternative of refusing permission for the offloading activities ari movenent of the SGSAs over SRS roads.

Iternatives available to CNSI should DOE choose the no action alternative were: use of other docking facilities, overland rail movement, and overland road movement. These alternatives were not considered reasonable because there are no other docks on the South Carolina side of the Savannah River that could accommodate oversize/overweight loads of this magnitude, nor are there any Savannah River bridges that could handle the weight should docks on the Georgia side be considered. The alternatives of overland rail or road movement of the SGSAs were not selected because railroad and hignway bridges could not sustain the weight. 
ENVIRONMENTAL IMPACTS: The potential environmental impacts of DOE permitting the CNSI offloading activities to support the movement of the SGSAs across SRS were determined to be temporary and insignificant.

The modification activities at the SRS boat ramp would be minor and have been reviewed and authorized by the U.S. Army Corps of Engineers (COE) under Nationwide Permit \#3. Modifications to the existing 15 -foot wide SRS boat ramp would be to remove upland vegetative growth and silt that has accumulated on and adjacent to the ramp to provide a 40-foot wide access to the ramp area for the barge to dock and offload the SGSAs. The silt, soil, and vegetative growth would be disposed at an approved landfill on SRS. CNist estinates approximately 17 cubic yards of sediment would be areciged 20 feet on ejther side of the centerline of the sRs boat ramp. To mathlain conpiiance with the COE nationwide permit, CNSI would not remove more than 25 cubic yards of material from below the Savannah River ordinary high water mark.

: שr.ilg tres time between the two proposed SGSA trips, the area orouid the SR.S boat ramp would be protected from the effects of erosion by the use of erosion mats. At the termination of the project: CNSI would restore the affected floodplain contours above the ordinary high water mark to pre-project conditions. Adherence to a DCE-approved soil erosion control plan by CNSI would be required before the proposed work is initiated. No wetlands on the SRS would be affected by this project. 
In accordance with DOE regulations for compliance with floodplain/ wetlands environmental review requirements (10 CFR Part 1022), DOE prepared an assessment for the area surrounding the SRS boat ramp. This assessment showed that the floodplain/wetlands within the immediate area would not be affected by the offloading activities, providing appropriate erosion control measures were implemented.

All environmental and safety risks have been determined to be minimal, as well as the potential for an accident during the offloading of the barge. Two SRS bridges would be temporarily modified to accomodate movement of the SGSAs across the site. All modifications would be done above the bridges; therefore, there wolid be no wetlands impacted.

DETERMINATION: The proposed granting of DOE permission to CNSI to rosify and use the SRS boat ramp on the Savannah River to facilitate offloading and movement of SGSAs across SRS does not constitute a major Federal action significantly affecting the quailly of the human environment within the meaning of NEPA. Therefore, an environmental impact statement is not required.

Issued at washington, D.C., this $2 .:$ day of $1,1,1992$.

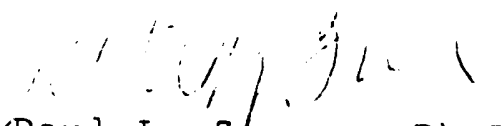
'Paul L. Zlemer, Ph.D. Assistant Secretary Environment, Safety and Health 

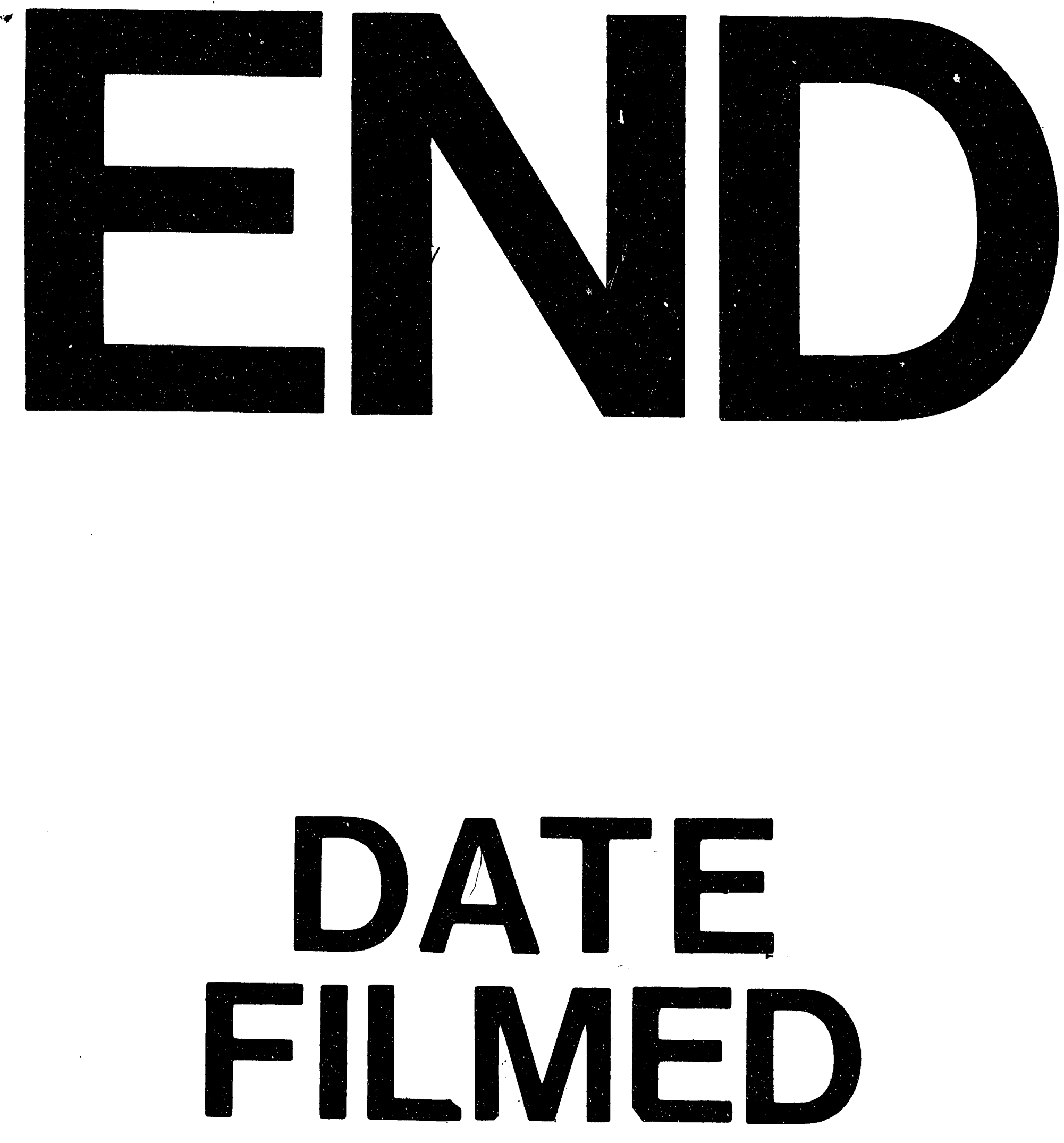

f

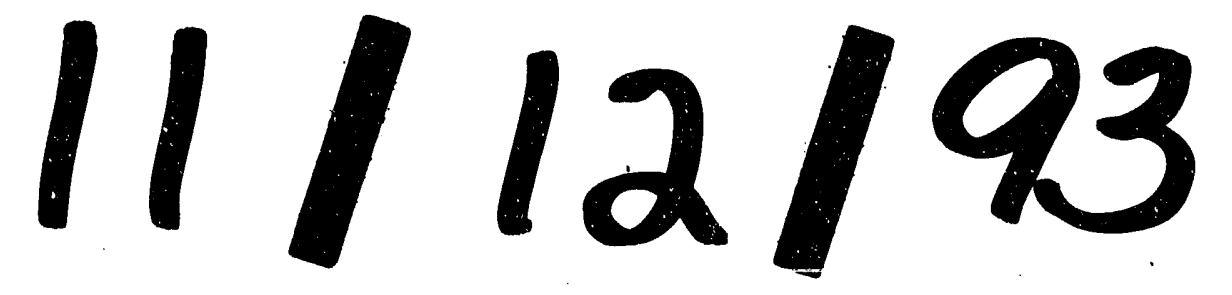


